\title{
The Export-Led Growth Hypothesis: A Panel Cointegration Approach in the Middle East and North Africa Countries (1980- 2017)
}

\author{
Ph.D. Candidate Ayat Abdelrahim Suliman Esaa (Çukurova University, Turkey) \\ Prof. Dr. Harun Bal (Çukurova University, Turkey) \\ Asst. Prof. Dr. Erhan İşcan (Çukurova University, Turkey)
}

\begin{abstract}
This study examines the hypothesis of the Export-Led Growth in the seven selected Middle East and North Africa countries, the hypothesis state that export growth driven by export promotion policies enhances overall economic growth. Empirical investigations have tended to focus attention on the direction of causality between exports and economic growth using Granger causality tests. However, the empirical results based on these tests are, at best, mixed and often contradictory.

The paper employs panel data analysis by utilizing the Pedroni panel cointegration, Pedroni Dynamic Ordinary Least Squares and Fully Modify Ordinary Least Squares, and Canning-Pedroni causality methods, a recent development in panel data econometrics, properties of integration and cointegration and consistency of parameters. The study considers the following three variables; Real Gross Domestic Product (GDP), Real exports (EXP) and Real import (IMP). Annual secondary data are obtained from the World Bank Development Indicator for seven MENA countries, Namely, Algeria, Egypt, Sudan, Jordan, Saudi Arabia, UAE, and Qatar.

The empirical results emphasize the existence of a positive relationship between Export and GDP. Results of waled and Z-bar Group statistics indicate the long-run unidirectional causality between Export and GDP, operates from Export to the GDP. It confirms the validity of Export-led growth hypothesis of the seven selected MENA countries. Empirical evidence suggests significant policy prescriptions; these countries should focus more on supporting export orientated industries through aid-for-trade, trade-capacity building schemes and other types of policies in order to promote economic growth.
\end{abstract}

\section{Introduction}

The export-led growth (ELG) hypothesis has been tested by many empirical studies in order to examine whether export growth driven by export promotion policies enhances overall economic growth. The determination of the causal relationship among exports and output growth bears significance owing to its important policy implications concerning convenient growth and development strategies and policies to pursue.

Previous studies on the ELG hypothesis, for the most part, confirmed its validity due to the high correlation amongst exports and output. Recent empirical investigations have would in general spotlight consideration on the direction of causality among exports and output growth utilizing Granger causality tests. Nevertheless, empirical evidence primarily lean on these tests are mixed and overwhelmingly contradictory (Aamer and Abu-Bader, 2001). The absence of a consistent causality relation among exports and output growth in ELG studies in general and for the MENA region, in particular, may be explained, in part, by the differences in the measures of exports, sample period considered and methodologies adopted.

Many developing countries, incorporating those in the MENA region, have pursued trade liberalization and export promotion policies as a desirable strategy for development and growth, especially, after the sturdy export performance and high economic growth rates of some East Asian countries. This change in the development strategies is based on the expectations that trade liberalization in general and export promotion, in particular, would result in the following: i) exports expand the market and help exploit economies of scale; ii) exportation mitigates the binding foreign exchange constraint to permit importation of the requirements of domestic production and exports from intermediate goods and capital, consequently increasing the production possibilities economy; iii) exports reinforce domestic efficiency via raise competition; and iv) exportation fosters the prevalence of technical knowledge through the suggestions of foreign buyers and learning by doing (Melise and Caroline, 2015).

A study of (Behar and Freund, 2011) shows that exports of MENA countries had been increasing extra rapidly compared to the exports from the rest of the world, refers to some proofs of convergence. However, based on the historical records of growth rate, in order to reach potential trade level, this would take 20 years for MENA countries. Moreover, the progress of export overall performance over the years is very slow and indicates that it can take two times as long to attain a potential level.

Economic growth in MENA countries has been comparatively slow since 1980. When East Asia and South Asia registered over threefold increase in real per capita income against 60 percent for that of the world, it was only 30 percent for MENA region (Behar and Freund, 2011). Although there are various conceivable contributing factors, several studies indicate a robust connection between income per capita and international trade flows. Whereas 
Greater openness encourages the movement of resources to the most productive use, which catalyzes returns on investment and thereby raises living standards.

Due to some constraints on trade regimes, MENA countries have missed out on global trade integration. Where trade policies such as high and complex tariffs have been referred to as the fundamental policy-induced barrier to intra-Arab trade (Saidi and Prasad, 2018). Also, factors such as insufficient skills and high logistics costs have been mentioned too in a publication of World Bank (1992). For that reason, many consider that inadequate integration is one of the causes of poor economic performance in the MENA region (Haddad, 1993).

The aim of this study is to examine the causality among exports and output growth, the direction, and size of this relation for seven selected MENA countries: Algeria, Egypt, Sudan, Jordan, Saudi Arabia, UAE, and Qatar. To serve the purpose, the study primarily consults and summarizes the results of earlier studies to develop a better framework of the study. It then proceeds to investigate the relation among real exports and output growth for the MENA countries stated above during 1980-2017 using Pedroni panel cointegration tests. Finally, a long-run cointegrating relation has been estimated in a panel set applying Fully Modified OLS (FMOLS) and Dynamic OLS (DOLS) along with the investigation of the causality among real exports and output growth adopting approach found by Canning and Pedroni (2008).

\section{Literature Review}

The relation between exports and output growth in an economy has for quite some time been a zone in international and development economics accepting a lot of research consideration. Depending on the basic concepts of economic theory, it can be suggested that exports contribute to output growth through the multiplier effect of foreign trade. The foreign trade multiplier analysis affirms that given the expenditure function; an export surplus will have an expansionary effect extent will depend on the marginal propensity to imports. Transmit of rare resources from low-productivity domestic industries to higher-productivity export industries leads to a rise in total productivity speeding up the growth of output.

A considerable number of studies have investigated the causality relation among exports and output growth. However, only a few researchers addressed particularly the subject for the MENA region. Some findings indicate that a significant and positive relationship exists among export and output growth. Most ELG studies on the MENA countries did not apply cointegration tests when the causality be examined among exports and output growth, also the majority of these studies are time series studies while the current study uses panel data analysis.

Pompino (1996) examined the validity of ELG hypothesis in some MENA countries applying cointegration and error correction model (ECM), a unidirectional causality from output growth to exports has been found in Algeria and Tunisia, while there is no causality for Sudan, Morocco, and Turkey. However when the investment has been introduced as a third variable, a bidirectional causality was found for Turkey and Tunisia and no change was found in the results for Algeria, Morocco, and Sudan. Using the error correction model (ECM) and vector autoregressive, Abu-Qarn and Abu-Bader(2001) attempted to examine the causality among exports and output growth in nine MENA countries. Empirical results show that when aggregate exports were considered estimation shows that the Export-led Growth hypothesis is not valid in the majority of the countries analyzed. While in case of manufactured exports only been considered, they found that there is no existence of causality in countries with relatively low shares of manufactured exports in total merchandise exports while there is a bidirectional causality for countries with relatively high shares. Husein (2010) investigated the ELG hypothesis in eight (MENA) countries in a multivariate framework by including trade as a third variable. He utilized the Johansen and Juselius cointegration procedure and error correction modeling to examine the ELG hypothesis. Empirical evidence affirms that a stable long-run equilibrium relation exists among real exports, real output, terms of trade.

In the case of the bivariate studies, Abual-Foul (2004) tested the validity of the ELG hypothesis in Jordan during the period (1976-1997). Citing a lack of a long sample, unit root tests have not carried and hence did not test for cointegration. As an alternative, three bivariate models have been employed, namely, a vector autoregressive (VAR) in levels, a vector autoregressive (VAR) in first differences, and an error correction model (ECM). Based on the three bivariate models, the study pointed out a unidirectional causality runs from exports to output. Hamdi (2013) examined the ELG hypothesis for Tunisia and Morocco employing a model based on the procedure of Toda and Yamamoto (1995). Empirical results affirm the validity of the ELG hypothesis in Tunisia, while in the case of Morocco results reveal the existence of import-led growth policy oriented. Also, there is no existence of bidirectional causality among imports and exports for both Tunisia and Morocco.

Applying Johansen-Juselius cointegration tests and error correction model, Husein (2009) tested the validity of the ELG hypothesis in Jordan, he found a presence of cointegration amongst real exports, real output, and terms of trade. Moreover, Granger causality tests based on the ECM suggested that there is a bidirectional causality amongst real exports and real output growth. Chia Yee Ee (2015) applied a panel data approach to investigate the validity of the export-led growth hypothesis for selected Sub-Saharan African (SSA) countries. Based on FMOLS and DOLS estimations, the empirical findings revealed that there is a long-run relationship among exports and economic growth. Additionally, results indicate a positive effect of exports, investment and government 
expenditure on economic growth. Athanasia and Emmanuel (2017) tested the validity of ELG hypothesis for the United Arab Emirates, concentrating on the causality among manufactured exports, primary exports and economic growth, the analysis revealed that the long-run contribution of manufactured exports to economic growth is more than primary exports. Also, results point out that over the long-run the Growth-Led Exports (GLE) hypothesis is valid in UAE, and there is a short-run bidirectional causal relation among manufactured exports and economic growth.

\section{Data and Methodology}

\subsection{Data Sources}

The analysis of panel data considers seven selected the Middle East and North Africa (MENA) countries. The priority of selecting has been specified to the countries with accessible data over 1980-2017 periods. In the study, data on variables (Exports, Gross Domestic Product, Imports, and consumer price index) have been obtained from the World Development Indicator (WDI) of the World Bank. Whereas, the data of exports and imports of goods and services and GDP have been divided by the consumer price index (CPI) to obtain real terms of variables. All the variables are used in the logarithmic form.

The general function can illustrate as follows;

$$
\ln G D P=f(\ln E X P, \ln I M P)
$$

\subsection{Econometric Model}

The inference of ELG hypothesis requires empirical investigation. With this objective, theoretical models for the study intending to analyze the causality relation between exports and output have been specified below.

$$
\begin{aligned}
& E X P=f(G D P) \\
& G D P=f(E X P)
\end{aligned}
$$

Since Granger Causality is figured by performing bivariate relapses, there are various distinctive ways to test causality for Granger in a panel data. Generally, bivariate regressions in a panel data can be illustrated as:

$$
\begin{aligned}
& y_{i, t}=\alpha_{0, i}+\alpha_{1, i} y_{i, t-1}+\cdots+\alpha_{k, i} y_{i, t-k}+\beta_{1, i} x_{i, t-1}+\cdots+\beta_{k, i} x_{i, t-k}+\epsilon_{i, t} \\
& x_{i, t}=\alpha_{0, i}+\alpha_{1, i} x_{i, t-1}+\cdots+\alpha_{k, i} x_{i, t-k}+\beta_{1, i} y_{i, t-1}+\cdots+\beta_{k, i} y_{i, t-k}+\epsilon_{i, t}
\end{aligned}
$$

$\mathrm{t}$ indicates the size of the panel time periods and $\mathrm{i}$ denote the size of the cross-section. The forms of panel causality tests vary in the hypotheses on the homogeneity of the coefficients in the cross-sections. This study employs the approach developed by Dumitrescu-Hurlin (2012), which permits the coefficients to be different across sections:

$$
\begin{gathered}
\alpha_{0, z} \neq \alpha_{0, j}, \neq \alpha_{1, i} \neq \alpha_{1, j}, \ldots, \alpha_{l, i} \neq \alpha_{\iota, j}, \forall_{i, j} \\
\beta_{1, i} \neq \beta_{1, j}, \ldots, \beta_{1, i} \neq \beta_{l, j} \neq \beta_{l, j}, \forall_{i, j}
\end{gathered}
$$

This test is calculated by exaggerating standard Granger causality regressions for each cross-section independently. Then taking the average of the statistics from the test, which are called W-bar statistics, shows the standardized version of this statistic, and follows a standard normal distribution called the Z-bar statistic.

\section{Empirical Results and Discussion}

\subsection{Unit root test}

In order to examine the presence of unit root in the panel data analysis, DF (Dickey-Fuller) and the ADF ( Augmented Dickey-Fuller) tests have been extended in order to perform a multi-unit root test for panel data approach. Heterogeneity in panel data analysis considers as a significant factor reflects complexity in time series. That means each individual in the panel set may not have the same features, and thus time series may differ in terms of being stationary or non-stationary (Chia Yee Ee,2016).

This study uses unit root tests of most leading works concerns panel data models include; Levin, Lin, and Chu (2002), Im, Pesaran, and Shin ( 2003), ADF (Augmented Dickey-Fuller) and Fisher tests. The logarithm of the variables; output growth (GDP), real Exports (EXP) and real Import (IMP) has been decided and then unit root tests are performed. Table 1. displays the results of unit root tests examined in levels, based on $\mathrm{T}$ statistics and probability values the variables are non-stationary at level [I (0)] which indicate a presence of unit root. Consequently, the first differences of the series were tested. Considering the first differences of variables, results show that series are stationary at [I (1)]. 


\begin{tabular}{|l|l|l|l|l|l|l|}
\hline \multicolumn{1}{|c|}{ variable } & \multicolumn{2}{c|}{ Ln(GDP) } & \multicolumn{2}{c|}{ Ln(Exp) } & \multicolumn{2}{c|}{$\begin{array}{l}\text { Ln(IMP) } \\
\text { trend }\end{array}$} \\
\hline & constant & $\begin{array}{l}\text { Constant and } \\
\text { trend }\end{array}$ & constant & $\begin{array}{l}\text { Constant and } \\
\text { trend }\end{array}$ & constant & \multicolumn{2}{c|}{ level } \\
\hline \multicolumn{7}{|c|}{} \\
\hline Levin,lin & 2.068 & 0.563 & 2.756 & 0.830 & 1.373 & -1.355 \\
\hline IPS & 2.118 & 0.559 & 2.042 & -0.706 & 2.195 & 0.097 \\
\hline ADF-fisher & 14.244 & 14.475 & 11.671 & 16.619 & 19.302 & 18.062 \\
\hline \multicolumn{7}{|c|}{ First difference } \\
\hline Levin,lin & $-4.855^{* *}$ & $-3.166^{* *}$ & $-8.241^{* *}$ & $-4.505^{* *}$ & $-7.843^{* *}$ & $-6.790^{* *}$ \\
\hline IPS & $-7.499^{* *}$ & $-6.526^{* *}$ & $-9.900^{* *}$ & $-8.413^{* *}$ & $-8.044^{* *}$ & $-7.148^{* *}$ \\
\hline ADF-fisher & $88.453^{* *}$ & $73.965^{* *}$ & $118.587^{* *}$ & $94.821^{* *}$ & $87.635^{* *}$ & $73.405^{* *}$ \\
\hline
\end{tabular}

Table 1: Results of Panel Unit Root Test

Note: ${ }^{* *}$, denote the rejection of the null hypothesis at $5 \%$ significance level.

\subsection{Panel cointegration test}

Stationarity of all the variables at first difference allows performing the Pedroni cointegration test so as to identify if there is any long-run relation exist amongst the variables. Pedroni $(2000,2004)$ proposes panel cointegration tests that consider heterogeneity by utilizing particular parameters that were permitted to differ crosswise over individual groups of the sample. There are seven different cointegration statistics in Pedroni tests, the first category includes four tests pooled "within" size and the second category consists of three other tests in the size "between" (group mean) effects.

Table 2 illustrates the cointegration tests results, the analysis reveals that five of the seven statistics in the Pedroni cointegration show that there is cointegration while the remain other tests show the opposite. Therefore, it can be declared that the three variables of analysis have a long-run cointegrating relation. Which means that output growth, 1 real Export, and real import act together in long-run for the selected MENA countries.

\begin{tabular}{|c|c|c|}
\hline \multicolumn{3}{|c|}{$\operatorname{Ln} \mathrm{GDP}_{\mathrm{i}}=\beta_{0}+\beta_{1} \ln \mathrm{EXP}_{\mathrm{i}}+\beta_{2} \ln \mathrm{IMP}_{\mathrm{i}}+\mathrm{u}_{\mathrm{i}}$} \\
\hline & Without trend & With trend \\
\hline \multicolumn{3}{|l|}{ Within dimension } \\
\hline Panel V-stat & $6.1120 * * *$ & $7.3306 * * *$ \\
\hline Panel ROH-stat & $-1.6905^{*}$ & $-1.8976^{*}$ \\
\hline Panel PP-stat & -1.0062 & $-2.2378^{*}$ \\
\hline Panel ADF-stat & $-3.0770 * *$ & $-5.4475 * * *$ \\
\hline \multicolumn{3}{|c|}{ Between dimension } \\
\hline Group ROH-stat & -0.1736 & 0.8260 \\
\hline Group PP-stat & 0.4766 & 0.7821 \\
\hline Group ADF-stat & $-1.4996^{*}$ & $-2.0239 *$ \\
\hline
\end{tabular}

Table 2: Pedroni Cointegration Test Results

Note: ***, **, *, refers to statistical significance at $1 \%, 5 \%$, and $10 \%$ levels.

\subsection{Panel cointegration estimation of DOLS and FMOLS}

The analysis of Pedroni's cointegration only examines the existence of cointegration, however, it does not have the ability to estimate the long-run relationship among the variables in the panel framework. Thus, Fully Modified Ordinary Least Square (FMOLS) and Dynamic Ordinary Least Square (DOLS) are employed in this study. The main point of applying two different estimation techniques is to examine the consistency of results to make a precise decision. In the cointegrated panel regression, FMOLS and DOLS estimators consider more reliable (Kao and Chiang, 2000).

FMOLS estimation corrects the problems of deviations in the standard fixed effect estimator that be caused by the existence of heteroscedasticity or/and autocorrelation problem. The method of DOLS has a characteristic of resolving the problem of deviations in the static regression that be caused by endogeneity (Fatih and Mehmet,2014). Moreover, FMOLS estimation allowing significant heterogeneity among the individual sections, consider the possibility of correlation exists amongst the constant and regressors and error term (Asteriou and Hall, 2007). 


\begin{tabular}{|c|c|c|c|}
\hline \multicolumn{4}{|c|}{$\mathrm{Ln}_{\mathrm{GDP}}=\beta_{0}+\beta_{1} \ln \mathrm{EXP}_{\mathrm{i}}+\beta_{2} \ln \mathrm{IMP}_{\mathrm{i}}+\mathrm{u}_{\mathrm{i}}$} \\
\hline variables & Coefficient & t statistic & P-value \\
\hline $\operatorname{Ln}(\mathrm{EXP})$ & 0.888254 & 2.649301 & 0.0087 \\
\hline Ln(IMP) & -0.711941 & -2.104718 & 0.0366 \\
\hline \multicolumn{4}{|c|}{$\operatorname{Ln} \mathrm{EXP}_{\mathrm{i}}=\beta_{0}+\beta_{1} \ln \mathrm{GDP}_{\mathrm{i}}+\beta_{2} \ln \mathrm{IMP}_{\mathrm{i}}+\mathrm{u}_{\mathrm{i}}$} \\
\hline variables & Coefficient & $\mathrm{t}$ statistic & P-value \\
\hline Ln(GDP) & 0.086422 & 2.521749 & 0.0125 \\
\hline Ln(IMP) & 0.984048 & 163.2938 & 0.0000 \\
\hline
\end{tabular}

Table 3: Results of panel DOLS estimation

Note: statistical significance accepts at 5\%.

Results of DOLS estimation in Table 3 show that there is a statistically significant long-run relationship among variables, exports in a positive and imports in a negative statistical way in accordance with the theoretical expectation. The elasticity of export variable was calculated as 0.888 . Which indicates that over long-run, a $1 \%$ increase in export volume across the 7 selected MENA countries brings about $0.88 \%$ percent increase in output. The second part of the results shows that output also affects the volume of real export in a positive statistically significant way in accordance with the theoretical expectation. The elasticity of output was estimated at 0.086 . Hence across the 7 selected MENA countries, a 1\% increase of output in the long-run the volume of real export nearly $0.086 \%$ constitutes an increase.

\begin{tabular}{|c|c|c|c|}
\hline \multicolumn{4}{|c|}{$\mathrm{Ln} \mathrm{GDP}_{\mathrm{i}}=\beta_{0}+\beta_{1} \ln \mathrm{EXP}_{\mathrm{i}}+\beta_{2} \ln \mathrm{IMP}_{\mathrm{i}}+\mathrm{u}_{\mathrm{i}}$} \\
\hline variables & Coefficient & t statistic & P-value \\
\hline $\operatorname{Ln}(\mathrm{EXP})$ & 0.619512 & 2.608580 & 0.0096 \\
\hline Ln(IMP) & -0.440176 & -1.842512 & 0.0666 \\
\hline \multicolumn{4}{|c|}{$\operatorname{Ln~EXP}_{\mathrm{i}}=\beta_{0}+\beta_{1} \ln \mathrm{GDP}_{\mathrm{i}}+\beta_{2} \ln \mathrm{IMP}_{\mathrm{i}}+\mathrm{u}_{\mathrm{i}}$} \\
\hline variables & Coefficient & t statistic & P-value \\
\hline Ln(GDP) & 0.078642 & 2.214157 & 0.0277 \\
\hline Ln(IMP) & 0.985089 & 152.3052 & 0.0000 \\
\hline
\end{tabular}

Table 4: Results for Panel FMOLS

Note: statistical significance accepts at $5 \%$.

Table 4 displays the results of FMOLS method, the analysis points out that in the long-run both exports and imports affect output, respectively, in a positive and negative statistically significant signs. The elasticity of export was estimated as 0.6195 . Thus, in the long run, a $1 \%$ increase in the volume of Export across the 7 selected MENA countries causes an increase of around $0.62 \%$ in output. Also, the second part of the analysis reveals that output affects the volume of exports in a positive and statistically significant sign. The elasticity of output was estimated as 0.0786 . Which means that a $1 \%$ increase in output in the long run across the 7 selected MENA countries leads to $0.079 \%$ increase in the volume of real exports.

\subsection{Panel Causality Findings}

As indicated by the cointegration approach, if there is a long-run relation amongst variables in all groups, a causality link must exist in no less than one direction. The causality relationship among Exports and output growth has been researched utilizing the technique prescribed by Canning and Pedroni (2008). This technique bears pivotal significance in that it gives information about the existence as well as the direction of long-run causality among the variables and also the sign of this causal relation (Melike and Eda, 2015).

\begin{tabular}{|l|l|c|c|l|}
\hline direction & Null hypothesis & Wald stat & Zbar-stat & p-value \\
\hline EXP $\rightarrow$ GDP & EXP does not homogeneously cause GDP & 6.90734 & 9.81253 & 0.0000 \\
\hline GDP $\rightarrow$ EXP & GDP does not homogeneously cause EXP & 1.33013 & 0.44932 & 0.6532 \\
\hline
\end{tabular}

Table 5: Panel Causality Results of Export and Economic Growth

Note: statistical significance accepts at 5\%.

According to the panel causality results, as Table 5 illustrates, the Waled and Z-bar statistics indicate a unidirectional causality relation among export and output. when the causality at the first phase across the panel running from export to the output is examined, the null hypothesis H0 (EXP does not homogeneously cause GDP) is rejected at 5\% level of significance. Within this frame, the results of the panel causality point out the existence of a long-run causality relation ranging from export to output. The second phase when a long term causality from GDP to real export was tested, the null hypothesis H0 (GDP does not homogeneously cause EXP) cannot be rejected at $5 \%$ level of significance. Therefore, the findings demonstrate no existence of a long-run causality link ranging from output to export. 


\section{Conclusions}

Using Johansen approach to panel cointegration, this study attempts to investigate the validity of ELG hypothesis in seven selected MENA countries, namely, Algeria, Egypt, Sudan, Jordan, Saudi Arabia, UAE, and Qatar. Unequivocally, in the case of encouraging exportation, as has been recommended by numerous international foundations and notable economists is the main strategy in order to improve the growth in the economy.

From the empirical results, it was seen that the first differences of time series utilized in the investigation of panel unit root are stationary at the 5\% level of significance, implying that the investigated variables (Exports (lnexp), Imports (lnimp) and output (lnGDP)) are integrated of order [I(1)]. Accordingly, the cointegration analysis has been performed. Results of Pedroni cointegration tests refer to the existence of a long-run cointegrating relation amongst the variables.

The long-run cointegration relationship is examined by utilizing FMOLS and DOLS estimators. As indicated by the estimations of DOLS test, GDP elasticity of real exports volume is determined as 0.888 . In other words, a $1 \%$ increase in real export in the seven selected MENA countries results in nearly $0.89 \%$ percent increases in GDP over the long-run. Moreover, as pointed out by DOLS estimators, in the long-run the elasticity of real export of GDP is computed as 2.649. This indicates that a 1\% increase in GDP for the seven selected MENA countries gives a rise of around $2.65 \%$ in the total real export.

As specified by FMOLS estimators, GDP elasticity of real export is calculated as 0.6195 . That is to say, over the long-run a $1 \%$ increase in real exports across the seven selected MENA countries leads to an increase of around $0.62 \%$ in GDP. Also, the FMOLS results refer to that the real export elasticity of GDP is indicated as 0.0786 . In other words, over the long-run, a 1\% increase in GDP in the seven selected MENA countries leads to an increase of nearly $0.079 \%$ in the real export. Eventually, it can be concluded that both the results from FMOLS and DOLS estimators are consistent with each other.

Based on statistics of waled and z-bar, panel Granger causality results point out unidirectional causality relations among export (EXP) and output (GDP), this unidirectional causality relationship runs from Export towards output at the $5 \%$ level of significance. Which confirm the validity of Export-led growth hypothesis over the data of seven selected MENA countries during (1980-2017). These empirical findings have an important implication whether seem to propose that export plays a significant role as an engine for economic growth, hence, policy-makers should, therefore, pursue policies that promote export expansion.

\section{References}

- Aamer Abu-Qarn and Suleiman Abu-Bader, 2001. "The Validity of the ELG Hypothesis in the MENA Region: Cointegration and Error Correction Model Analysis", Department of Economics, Ben-Gurion University of the Negev, MPRA 1116.

- Alberto Behar and Caroline Freund, 2011. "The Trade Performance of the Middle East and North Africa", International Monetary Fund, world bank, Working Paper 53, p. 24-27.

- Baltagi, B. H, 2011. Econometrics. Fifth Edition, Springer, New York.

- Bassam Abual-Foul (2004) Testing the export-led growth hypothesis: evidence from Jordan, Applied Economics Letters, 11, p. 393-396.

- Canning D. \& Pedroni, P, 2008. "Infrastructure, Long-run Economic Growth and Causality Tests for Cointegrated Panels", The Manchester School, 76 (5).

- Chia Yee, 2016, "Export-Led Growth Hypothesis: Empirical Evidence from Selected Sub-Saharan African Countries", Procedia Economics and Finance, p. 232 - 240.

- Dimitrios Asteriou and Stephen G.Hall, 2007. Applied Econometrics: A modern Approach using E.views and Microfit, Palgrave Macmillan, New York.

- Diwan, Ishac Squire, Lyn MNA Diwan, Ishac Squire, 1992. Economic and social development in the Middle East and North Africa, World Bank, http://documents.worldbank.org/curated/en/191861468753028968/Economic-and-social-development-inthe-Middle-East-and-North-Africa.

- Faith yardimcioglu, T. G. and M. Altundemir, 2014. "Education and Economic Growth: A Panel Cointegration Approach in OECD Countries (1980-2008)", Education and science, 39.

- Gujarati, D. N., 2004. Basic Econometrics, Fourth Edition, the McGraw-Hill, New York.

- Haddad Mona, 1993. The link between trade liberalization and multi-factor productivity: the case of Morocco (English). Middle East and North Africa working paper, World Bank. http://documents.worldbank.org/curated/en/772151468774000940/The-link-between-trade-liberalizationand-multi-factor-productivity-the-case-of-Morocco. 
- Helmi Hamdi, 2013. "Testing Export-led Growth in Tunisia and Morocco: New Evidence using the Toda and Yamamoto procedure", Cergam CAE- Aix-Marseille University.

- Husein, J., 2009. "Export-Led Growth Hypothesis: A Multivariate Cointegration and Causality Evidence for Jordan", The Journal of Developing Areas, 42 (2).

- Im, K. S. Pesaran, M. H. \& Shin, Y. ,2003. "Testing for unit roots in heterogeneous panels", Journal of Econometrics, 115, p.53-74.

- Jamal Husein, 2010. "Export-led Growth Hypothesis in the MENA region: a multivariate cointegration, causality and stability analysis", Applied Econometrics and International Development, Applied Economics Letters, 11, p.393-96.

- Kao, C., Chiang, M.H., 2000. "On the estimation and inference of a cointegrated regression in panel approach”, Economic Modeling, 23, p.987-992.

- $\quad$ Levin, A., Lin, C. \& Chu, C.J., 2002. "Unit root tests in panel data: Asymptotic and finite sample properties", Journal of Econometrics, 108, p.1-24.

- Melike Bidirici , Eda Bohur ,2015. "Design and Economic Growth: Panel Cointegration and Causality Analysis”, Procedia - Social and Behavioral Sciences, 210 , p.193 - 202.

- Melise Jaud and Caroline Freund, 2015. "Promoting Exports in the Middle East and North Africa", first MENA Trade Workshop, Tunis, p.14-15.

- Pedroni, P., 2000. "Fully-Modified OLS for Heterogeneous Cointegrated Panels", Advances in Econometrics, 15, p.93-130.

- Pedroni, P., 2001. "Purchasing power parity tests in cointegrated panels", Review of Economics and Statistics, 83, p.727-731.

- Pomponio, X.Z., 1996. “A Causality Analysis of Growth and Export Performance”, Atlantic Economic Journal, 24, p. 168-176.

- $\quad$ Rifat Tekin, 2012. "Economic growth, exports and foreign direct investment in Least Developed Countries: A panel Granger causality analysis”, Economic Modelling, 29, p.868-878. 